\title{
Rancang bangun die set sebagai alat bantu press tool untuk proses V-bending stainless steel
}

\author{
Rusdi Nur ${ }^{1)^{\star}}$, Muhammad Arsyad Suyuti ${ }^{2}$, Muhammad Iswar ${ }^{3)}$ \\ 1, 2) Jurusan Teknik Mesin Politeknik Negeri Ujung Pandang, Jalan Perintis Kemerdekaan Km. 10 Makassar \\ ${ }^{2)}$ Departemen Teknik Mesin, Universitas Indonesia, Kampus Depok
}

Naskah diterima 24/07/2021; direvisi 15/08/2021; disetujui 30/08/2021

doi: https://doi.org/10.24843/JEM.2021.v14.i01.p04

\begin{abstract}
Abstrak
Press tool merupakan alat bantu produksi yang banyak digunakan dalam industri manufaktur untuk pembentukan logam termasuk proses bending material pelat. Press tool terdiri dari die set yang digunakan untuk memotong maupun membentuk suatu produk atau komponen dari lembaran pelat logam dengan menggunakan mesin press sebagai alat penekan yang dapat menghasilkan produk dengan kualitas yang seragam dan waktu yang singkat. Tahapan dalam proses rancang bangun die set terdiri dari beberapa tahapan, yaitu: 1) tahap perancangan dengan menggunakan software Autodesk Fusion 360, 2) tahap pembuatan dengan menggunakan mesin perkakas beserta kelengkapannya, 3) tahap perakitan setiap komponen yang dibuat dan standar menjadi stu die set yang lengkap, 4) tahap pengujian die set dengan melakukan uji tekan pada mesin uji tekan (UTM Galdabini) dengan parameter uji yang bervariasi. Hasil pengujian tekuknya menunjukkan bahwa gaya tekuk yang diperlukan dalam penekukan pelat stainless steel dengan ketebalan $1 \mathrm{~mm}$ adalah berkisar $92 \mathrm{~N}-125 \mathrm{~N}$, sedangkan untuk ketebalan $2 \mathrm{~mm}$ berkisar $113 \mathrm{~N}-163 \mathrm{~N}$. Adapun sudut tekuk (bending) yang dihasilkan adalah $107^{\circ} 45^{\prime}-115^{\circ} 45^{\prime}$ untuk ketebalan $1 \mathrm{~mm}$, dan $100^{\circ} 20^{\prime}-116^{\circ} 45^{\prime}$ untuk ketebalan $2 \mathrm{~mm}$. Adapun kesimpulan yang diperoleh adalah die set yang dirancang dan dibuat ini telah menunjukkan performansi dan memenuhi syarat sebagai press tool yang dapat menekuk pelat bahan stainless steel.
\end{abstract}

Kata kunci: Die set, Press tool, V-Bending, stainless steel

\begin{abstract}
Press tools, as production aids, are widely used in the manufacturing industry for metal forming, including the bending of plate materials. The press tool consists of a die set used to cut or shape a product or component from sheet metal by using a press machine as a pressing tool that can produce products with uniform quality and in a short time. The stages in the die set design process consist of several stages, namely: 1) the design stage is carried out using Autodesk Fusion 360 software, 2) the manufacturing stage is carried out using machine tools and their accessories, 3) the assembly stage of each component both made and standard become a complete stu die set, 4) the stage of testing the die set by performing a compression test on a compression testing machine (UTM Galdabini) with various test parameters. The results of the buckling test show that the bending force required for bending a stainless steel plate with a thickness of $1 \mathrm{~mm}$ is in the range of $92 \mathrm{~N}-125 \mathrm{~N}$, while for a thickness of $2 \mathrm{~mm}$ it ranges from $113 \mathrm{~N}-163 \mathrm{~N}$. The bending angle produced is $107^{\circ} 45^{\prime}-115^{\circ} 45^{\prime}$ for a thickness of $1 \mathrm{~mm}$, and $100^{\circ} 20^{\prime}-116^{\circ} 45^{\prime}$ for a thickness of $2 \mathrm{~mm}$. The conclusion obtained is that this die set designed and made has shown performance and meets the requirements as a press tool that can bend stainless steel plates.
\end{abstract}

Keywords: Die set, Press tool, V-Bending, stainless steel

\section{Pendahuluan}

Saat ini proses pembentukan pelat logam pada industri permesinan berkembang cukup pesat khususnya pada proses bending. Proses bending adalah proses deformasi secara plastik dari logam terhadap sumbu linier dengan hanya sedikit atau hampir tidak mengalami perubahan luas permukaan dengan pembentukan pelat lembaran melalui tekanan punch dan die pembentuk. Dalam proses penekukan terjadi pemuluran atau peregangan pada sumbu bidang netralnya sepanjang daerah tekukan yang menghasilkan garis tekuk yang lurus [1]. Proses pembentukan pelat logam banyak dikerjakan pada berbagai industri manufaktur yang yang dipicu oleh banyak penggunaan teknologi mekanis dalam kehidupan masyarakat sehari-hari yang produknya atau komponennya terbuat dari logam pelat.

Bending atau tekuk adalah proses mengubah pelat logam pada alat press dengan cara pelat ditekan oleh punch sampai terbentuk bendingan sesuai bentuk die.
Dalam proses bending distribusi tegangan-regangan (stress-strain) merupakan hal yang sangat penting agar tercapai hasil bending yang sempurna sesuai dengan bentuk yang diinginkan. Sehingga ketika beban dihilangkan, material mencoba untuk mengambil bentuk aslinya dan material yang dibengkokkan akan kembali karena adanya peregangan. Perilaku material ini yang dinamakan springback [2]. Dalam proses bending terdapat beberapa parameter yang mempengaruhi hasil springback antara lain radius punch dan die, sudut punch dan dies, clearance antara punch dan die, kondisi gesekan baik statis dan dinamis, ketebalan plat, modulus elastis, dan dimensi material.

Salah satu alat bantu produksi yang banyak digunakan dalam industri manufaktur untuk pembentukan logam termasuk proses bending material pelat yaitu press tool. Press tool merupakan jenis alat bantu yang digunakan untuk memotong maupun membentuk suatu produk atau komponen dari 
lembaran pelat logam dengan menggunakan mesin press sebagai alat penekan yang dapat menghasilkan produk berkualitas yang seragam dan waktu singkat.

Sebelumnya telah dilaksanakan pembuatan alat bantu Simple Press Tool untuk bending V bottoming. Alat bantu mikro press tool ini dilengkapi dengan dies dan punch berbentuk $V$ bersudut $90^{\circ}$ yang berfungsi sebagai alat bantu bending $\mathrm{V}$ untuk lembaran logam yang tipis lebar garis bending maksimal $50 \mathrm{~mm}$. Penilitian ini menggunakan material baja St. 42. Pada alat bantu ini masih terdapat kekurangan kelonggaran suaian bushing yang tidak standar sehingga pada top plate maupun bottom plate goyang pada saat beroperasi. Sudut bending pelat hasil bending alat ini umum lebih besar dari $90^{\circ}$. Simple press tool ini dibuat khusus untuk uji eksperimen bending $V$ skala laboratorium [3]. Penelitian lainnya pembuatan press tool alat bending $\mathrm{V}$ dengan die berbentuk air bending dan material pelat yang dibending yaitu baja St.37. Air bending adalah salah satu metode penekukan, di mana benda kerja tidak benar-benar menyentuh seluruh bagian tool (punch dan die). Istilah lain dari air bending adalah partial bending atau free bending. Pada penekukan jenis ini, benda kerja hanya bersentuhan dengan dua titik ujung die dan satu titik ujung punch. Oleh karena itu, penekanan terhadap benda kerja tidak sampai menyentuh dasar die. Press tool ini memiliki dengan konstruksi yang sederhana dan terdiri dari tiga sub rakitan utama yaitu sub-rakitan die set, punch dan die. Namun konstruksi press tool ini masih memiliki beberapa kelemahan yaitu komponen guide post tidak presisi dan suaian top pelat tidak standar sehingga tingkat kepresisian alat bantu tersebut masih kurang. Alat ini juga merupakan alat kaji eksperimen skala laboratorium [4].

Dari hasil penelitian di atas belum didapatkan hasil yang maksimal baik dari segi konstruksi press tool maupun kepresisian yang dihasilkan. Oleh karena itu penulis berinisiatif melakukan suatu pengembangan desain dan uji material dengan menggunakan stainless steel agar diperoleh hasil yang maksimal baik dari segi konstruksi press tool maupun kepresisian hasil penekukan. Stainless steel merupakan material pelat yang banyak digunakan dalam industri rumah tangga dan transportasi Adapun bagian yang ingin dikembangkan yaitu terletak pada desain top plate, bushing, punch, die, bottom plate, pilar, dan bahan uji.

\section{Metode Penelitian}

\subsection{Waktu dan Tempat Penelitian}

Proses pembuatan alat ini dilaksanakan mulai dari bulan Februari hingga September 2020 di Bengkel Mekanik dan Laboratorium Mekanik Jurusan Teknik Mesin Politeknik Negeri Ujung Pandang.

\subsection{Alat dan Bahan yang Digunakan}

Dalam proses perancangan press tool, desain die set alat bantu ini digambar dengan menggunakan software Autodesk Fusion 360 (Educational Licence) untuk semua komponen yang dibuat.

Pada pembuatan press tool ini, komponen yang digunakan terdiri dari komponen yang dibuat dan komponen standar atau tersedia di pasaran. Bahan- bahan komponen yang dibuat dan komponen standar tersebut adalah sebagai berikut:

- Baja persegi $60 \times 60 \mathrm{~mm}$

- Pelat baja dengan ketebalan $22 \mathrm{~mm}$

- Baja karbon dengan ketebalan $30 \mathrm{~mm}$

- Baja bulat diameter $30 \mathrm{~mm}$

- Pelat stainless steel dengan tebal $1 \mathrm{~mm} \& 2 \mathrm{~mm}$

- Pegas tekan

- Baut dan mur serta Bushing

Sedangkan peralatan yang digunakan adalah mesin bubut, mesin frais, mesin gergaji, mesin bor, mesin gerinda dan mesin universal testing machine (UTM) Galdabini dan kelengkapannya.

\section{Hasil dan Pembahasan}

\subsection{Proses Perancangan Die Set}

Perancangan die set dilakukan dengan membuat desain dengan menggunakan Autodesk Fusion 360 [5][6]. Adapun desain dari komponen-komponen die set adalah sebagai berikut:

1. Top Plate

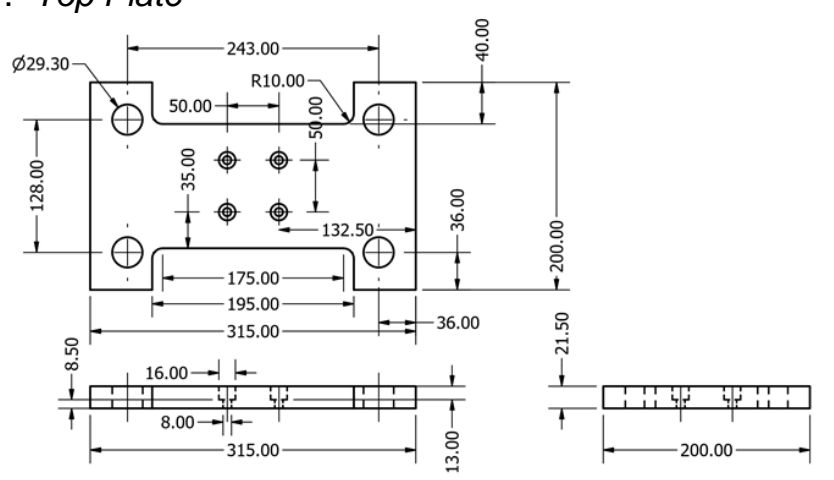

2. Bottom Plate
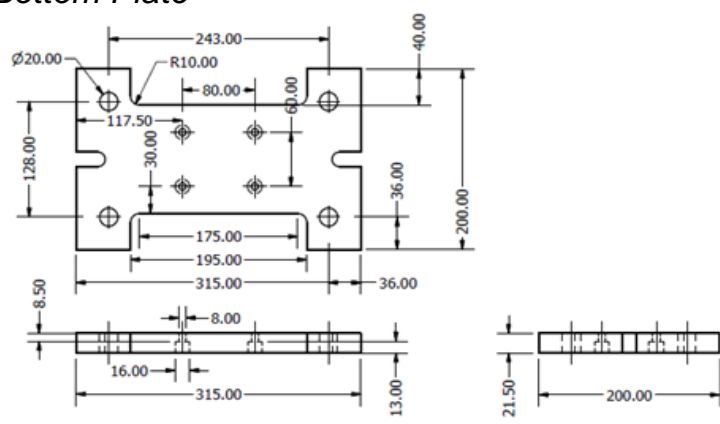

3. Poros

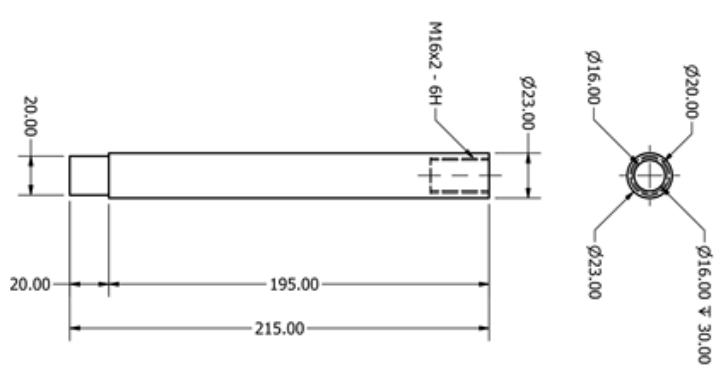

4. Pegas Tekan 


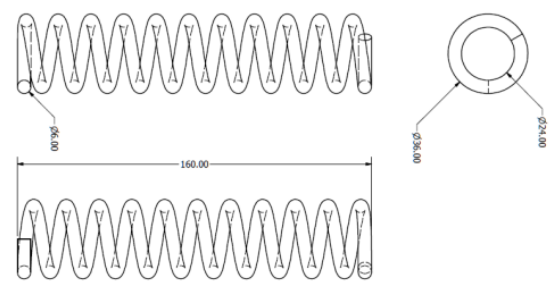


5. Pencekam Die

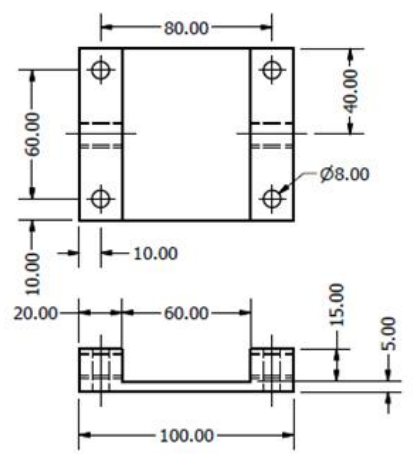

6. Pencekam Punch

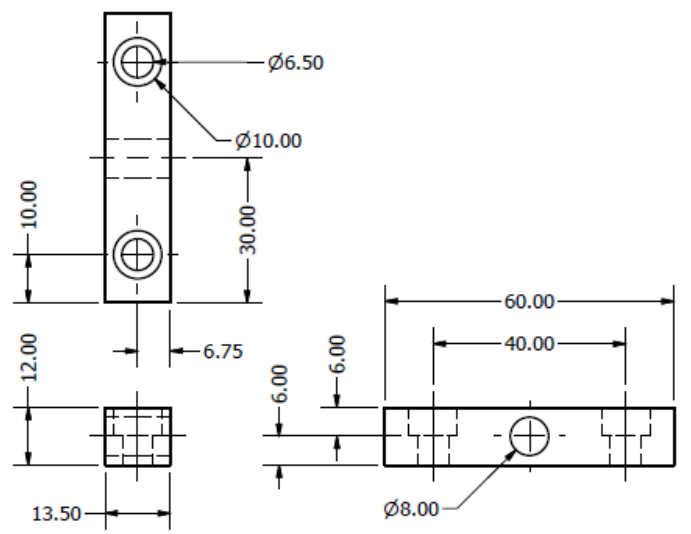

7. Bushing

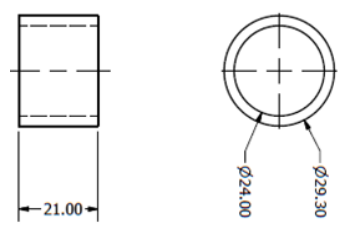

8. Ring

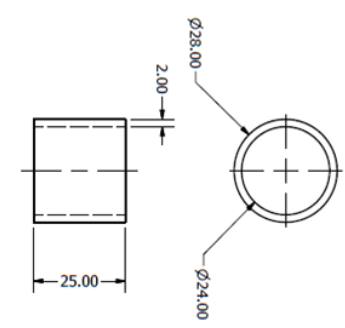

9. Pengunci Pilar dan Pelat
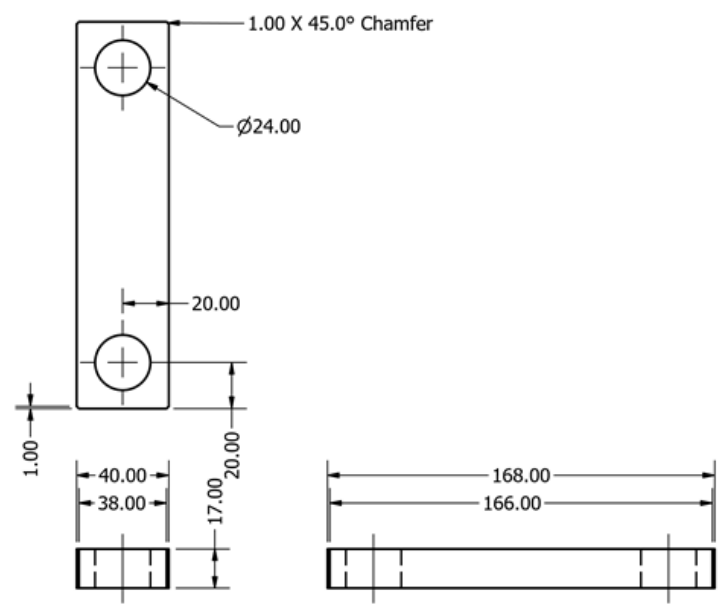

Desain punch dan die terlebih dahulu dibuat di Autodesk Fusion 360 sebelum dilakukan proses permesinan sehingga ukuran dan bentuk punch dan die presisi. Adapun desain punch dan die sebagai berikut:

- Punch; Punch terbuat dari pelat baja bahan St 42. Sudut punch yang dipakai adalah $80^{\circ}, 85^{\circ}$, dan $90^{\circ}$. Adapun varian radius punch adalah $2 \mathrm{~mm}, 4 \mathrm{~mm}$, dan $6 \mathrm{~mm}$.
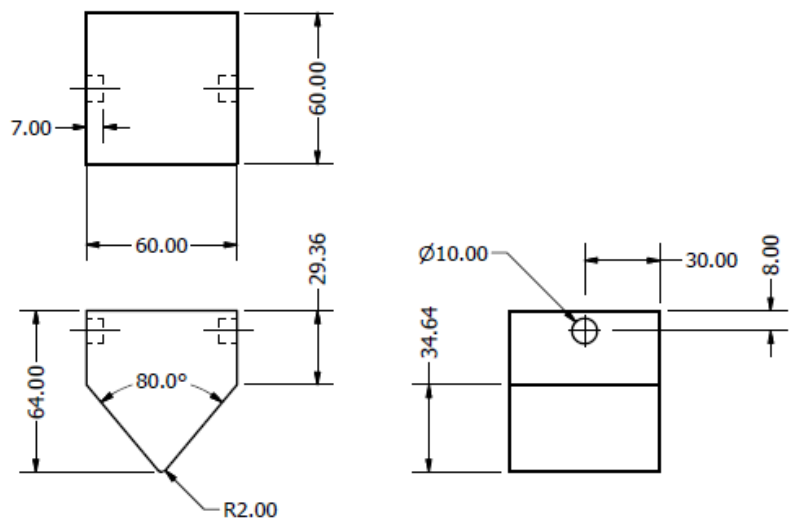

Die; Die terbuat dari baja berbentuk kotak dengan bahan St 42 . Sudut die yang dipakai adalah $90^{\circ}$.
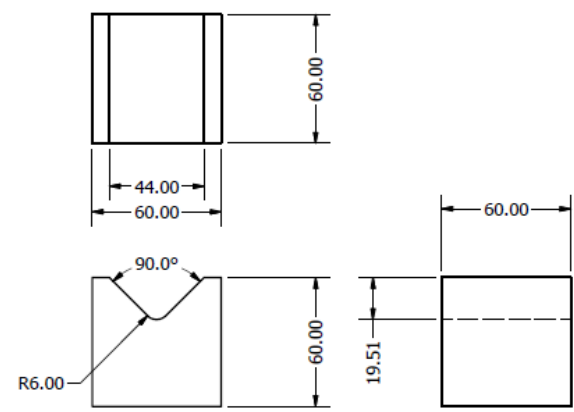

\subsection{Proses Pembuatan Die Set}

Pada proses pembuatan alat bantu bending $V$ untuk material stainless steel melalui beberapa tahapan pembuatan komponen sampai assembly. Adapun tahapan-tahapan itu adalah sebagai berikut:

1. Top Plate; Proses pembuatan top plate adalah sebagai berikut:

- Pelat terlebih dipotong menggunakan mesin gerinda setelah itu di facing menggunakan mesin frais sehingga mencapai ukuran $315 \mathrm{~mm}$ $x 200 \mathrm{~mm}$.

- Kemudian dibor dengan diameter $28 \mathrm{~mm}$ dan 5 $\mathrm{mm}$ hingga menembus pelat. fungsi lubang ini adalah sebagai penepat bushing.

- Pembuatan alur pada pelat dengan menggunakan mesin frais.

- Pembuatan ulir dengan tap manual M8 x 1.0.

2. Bottom Plate; Proses pembuatan bottom plate adalah sebagai berikut:

- Pelat terlebih dahulu dibor dengan diameter 25 $\mathrm{mm}$ hingga menembus pelat. fungsi lubang ini adalah sebagai penepat bushing.

- Pembuatan alur pada pelat dengan menggunakan mesin frais.

3. Poros/Pilar; Proses pembuatan poros adalah sebagai berikut:

- Memotong material terlebih dahulu dengan ukuran $260 \mathrm{~mm}$ menggunakan mesin gergaji.

- Facing material dari ukuran $\varnothing 25,4 \mathrm{~mm}$ menjadi $\varnothing 23 \mathrm{~mm}$ dengan menggunakan mesin bubut. 
- Facing material dari ukuran panjang $260 \mathrm{~mm}$ menjadi $240 \mathrm{~mm}$ dengan menggunakan mesin bubut.

- Selanjutnya membuat lubang untuk pengunci pilar dengan menggunakan mata bor hingga mencapai ukuran $\varnothing 15 \mathrm{~mm}$.

- Kemudian membuat ulir dalam dengan menggunakan tap M16 X $2.0 \mathrm{~mm}$.

4. Pencekam Die; Proses pembuatan pencekam die adalah sebagai berikut:

- Facing terlebih dahulu material menggunakan mesin frais.

- Pembuatan alur pada pelat dengan menggunakan mesin frais.

- Pelat terlebih dahulu dibor dengan $\varnothing 7 \mathrm{~mm}$ hingga menembus pelat. Fungsi lubang ini adalah sebagai penepat baut untuk penjepit die.

5. Die; Proses pembuatan die adalah sebagai berikut:

- Facing material dengan ukuran 60 x 60 x 60 mm menggunakan mesin frais.

- Membuat sudut dengan bentuk $V 85^{\circ}$ dengan mesin frais.

6. Pencekam Punch; Proses pembuatan pencekam punch adalah sebagai berikut:

- Pembuatan alur pada pelat dengan menggunakan mesin frais.

- Pelat terlebih dahulu dibor dengan diameter 6 $\mathrm{mm}$ hingga menembus pelat. Fungsi lubang ini adalah sebagai penepat baut untuk penjepit die.

7. Punch; Proses pembuatan punch adalah sebagai berikut:

- Memotong material terlebih dahulu menggunakan mesin gergaji.

- Facing material dengan ukuran 60 x 79,04 mm menggunakan mesin frais.

- Membuat alur dengan lebar ukuran 10 mm kedalaman $10 \mathrm{~mm}$ dengan mesin frais.

- Membuat sudut dengan bentuk V $85^{\circ}$ serta radius $2^{\circ}$.

- Mengebor material dengan diameter $6 \mathrm{~mm}$.

8. Bushing; Proses pembuatan bushing adalah sebagai berikut:

- Facing material dimesin bubut hingga mencapai ukuran $\varnothing 29.30 \mathrm{~mm}$.

- Setelah difacing di mesin bubut material dipotong hingga mencapai ukuran panjang 21 $\mathrm{mm}$ menggunakan mesin gergaji.

- Selanjutnya membuat lubang dengan $\varnothing 23$ mm dengan menggunakan mesin bubut.

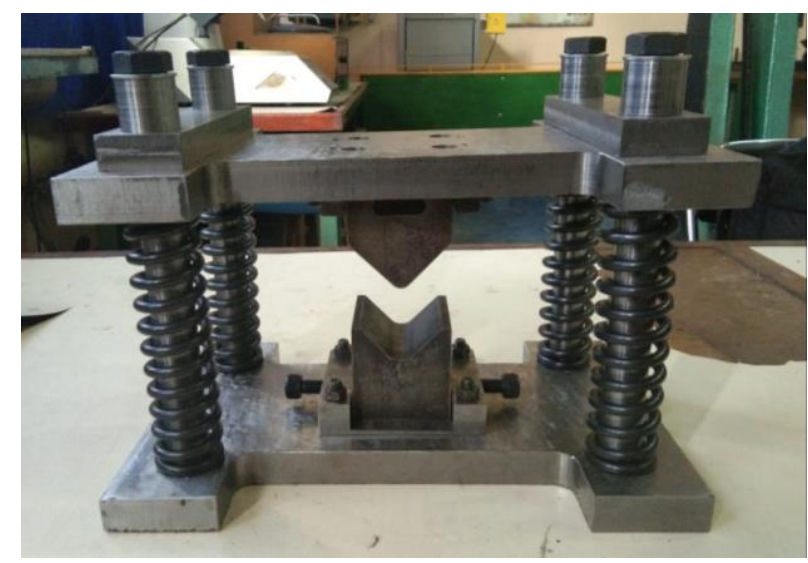

9. Pengunci Pilar dan Pelat; Proses pembuatan pilar dan pelat adalah sebagai berikut:

- Pelat terlebih dahulu difacing menggunakan mesin frais hingga mencapai ukuran $168 \mathrm{~mm} \mathrm{x}$ $17.00 \mathrm{~mm}$.

- Kemudian pelat dibor dengan diameter $23 \mathrm{~mm}$ hingga menembus pelat. Fungsi lubang ini adalah sebagai penepat bushing.

- Pembuatan alur pada pelat dengan menggunakan mesin frais.

\subsection{Proses Perakitan Die Set}

Perakitan die set menjadi sebuah press tool dapat dilakukan dengan menggunakan software Autodesk Fusion 360 sebelum dirakit secara langsung. Hasil perakitan diperlihatkan dalam Gambar 1 dan 2.
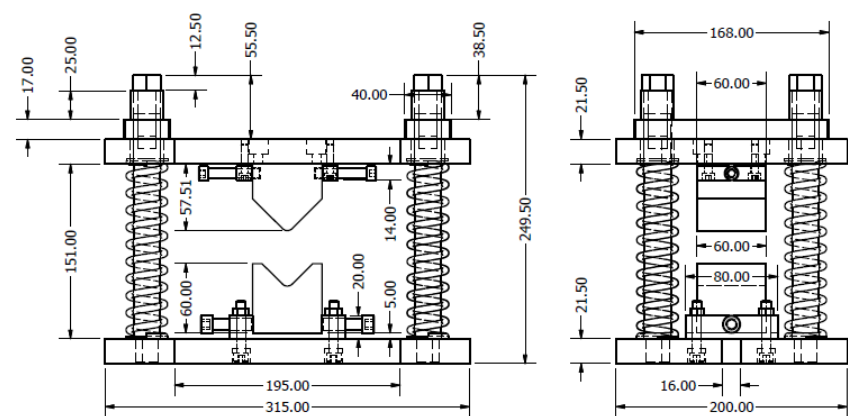

Gambar 1. Perakitan die set dengan software

Proses perakitan merupakan proses merangkai atau menggabungkan tiap komponen menjadi bentuk yang saling mendukung sehingga terbentuk suatu alat yang sesuai dengan yang direncanakan. Pada proses perakitan die set terdapat beberapa langkah. Adapun langkah-langkah tersebut adalah sebagai berikut:

- Menyambungkan bottom plate dengan 4 poros dengan suaian pas.

- Memasukkan pegas kedalam masing-masing poros.

- Menyambungkan pencekam punch dengan top plate.

- Memasang bushing pada top pate dengan suaian pas.

- Memasang top plate di atas poros dan pegas.

- Menyambungkan pengunci top plate dengan top plate dengan menggunakan mur.

Memasang pencekam die beserta die yang diinginkan serta, memasang punch pada pencekam punch dengan menggunakan baut.

\section{Gambar 2. Hasil perakitan die set}

\subsection{Proses Pengujian Tekuk Die Set}

Perakitan die set menjadi sebuah press tool dapat dilakukan dengan menggunakan software Autodesk Fusion 360 sebelum dirakit secara langsung. Hasil perakitan diperlihatkan dalam Gambar 1 dan 2.

Data hasil analisis sifat mekanis untuk material pelat selengkapnya dapat dilihat pada Tabel 1 . 
Tabel 1. Data sifat mekanis material stanless steel ketebalan $1 \mathrm{~mm}$ dan $2 \mathrm{~mm}$

\begin{tabular}{|l|c|c|}
\hline Data Uji Tarik & $\begin{array}{c}\text { Tebal 1 } \\
\mathrm{mm}\end{array}$ & $\begin{array}{c}\text { Tebal 2 } \\
\mathrm{mm}\end{array}$ \\
\hline - Kekuatan Tarik Maks. (MPa) & 650 & 533.33 \\
- Tegangan Yielding (N/mm²) & 625 & 433.33 \\
- Regangan (\%) & 34 & 30 \\
- Reduksi Penampang (\%) & 5 & 1.7 \\
\hline
\end{tabular}

Perhitungan gaya pembebanan pada pelat logam stainless steel dapat ditentukan dengan prinsip gaya tekuk (Gambar 3) dan menggunakan persamaan sebagai berikut:

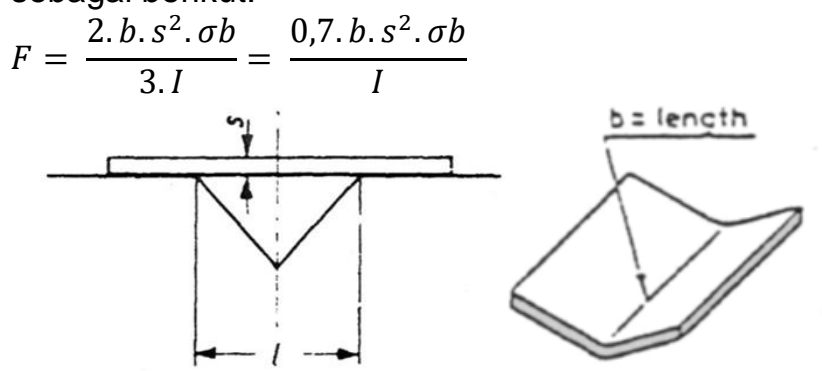

Gambar 3. Gaya Tekuk

Perhitungan besar gaya tekuk terhadap pelat stainless steel untuk tebal $1 \mathrm{~mm}$ adalah sebagai berikut:

$$
\begin{aligned}
& \sigma_{b}=0,8 \text { ot } \\
& \sigma_{b}=0,8 \times 650=520 \mathrm{~N} / \mathrm{mm}^{2}
\end{aligned}
$$

Dari hasil perhitungan tegangan bengkok tersebut, maka:

$$
\begin{aligned}
& F=\frac{0,7 \cdot b \cdot s^{2} \cdot \sigma b}{I} \\
& F=\frac{0,7 \times 50 \mathrm{~mm} \times 1^{2} \times 520 \mathrm{~N} / \mathrm{mm}^{2}}{44} \\
& F=413,636 \mathrm{~N}
\end{aligned}
$$

Dari hasil perhitungan di atas besar gaya yang dibutuhkan pada pelat stanless steel ketebalan $1 \mathrm{~mm}$ adalah $413,64 \mathrm{~N}$. Karena adanya gaya balik yang ditimbulkan oleh pegas maka besar gaya yang dibutuhkan semakin besar. Sehingga gaya yang dibutuhkan harus diakumulasikan dengan gaya pegas 2357,95 N. Jadi gaya yang digunakan untuk membengkokkan pelat stanless steel adalah 2771,59 $\mathrm{N}$.

Sedangkan perhitungan besar gaya tekuk terhadap pelat stainless steel untuk tebal $2 \mathrm{~mm}$ adalah sebagai berikut:

$$
\begin{aligned}
& \sigma_{b}=0,8 \sigma \mathrm{t} \\
& \sigma_{b}=0,8 \times 533.33=426.66 \mathrm{~N} / \mathrm{mm}^{2}
\end{aligned}
$$

Dari hasil perhitungan tegangan bengkok tersebut, maka diperoleh:

$$
\begin{aligned}
& F=\frac{0,7 \cdot b \cdot \mathrm{s}^{2} \cdot \sigma b}{I} \\
& F=\frac{0,7 \times 50 \mathrm{~mm} \times 2^{2} \times 426.66 \mathrm{~N} / \mathrm{mm}^{2}}{44} \\
& F=1357.2 \mathrm{~N}
\end{aligned}
$$

Dari hasil perhitungan di atas besar gaya yang dibutuhkan pada pelat stanless steel ketebalan $2 \mathrm{~mm}$ adalah 1357.2 N. Karena adanya gaya balik yang ditimbulkan oleh pegas maka besar gaya yang dibutuhkan semakin besar. Sehingga gaya yang dibutuhkan harus di akumulasikan dengan gaya pegas $2357,9545 \mathrm{~N}$. jadi gaya yang digunakan untuk membengkokkan pelat stanless steel adalah $3715.15 \mathrm{~N}$.

Selanjutnya, pengujian tekuk (bending) dilakukan dengan menggunakan mesin Universal Testing Machine (UTM) Merek Galdabini Tipe PM 100.

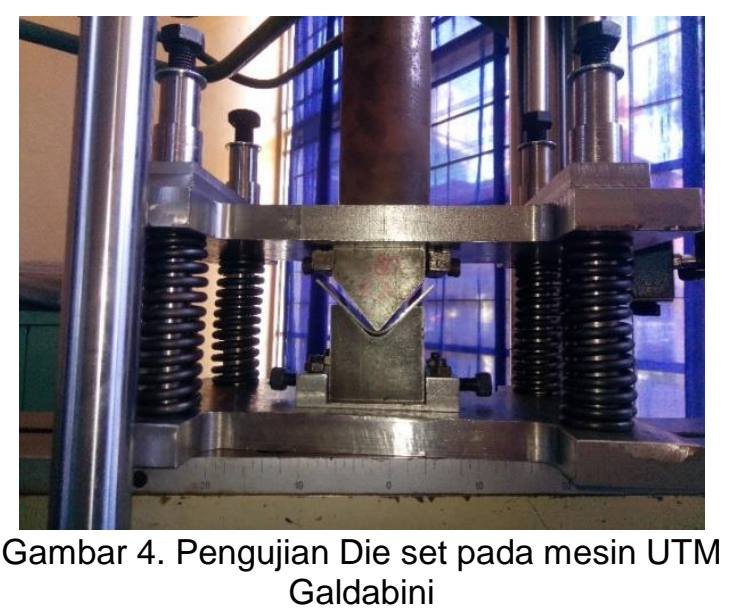

Pada proses pengujian dilakukan dengan variabel sudut punch, radius punch, langkah penekanan (stroke), dan ketebalan spesimen uji. Variasi Sudut punch yang dipakai adalah $80^{\circ}, 85^{\circ}$, dan $90^{\circ}$. Variasi radius puch yang digunakan adalah $2 \mathrm{~mm}, 4 \mathrm{~mm}$, dan $6 \mathrm{~mm}$. Langkah penenkanan (stroke) yang dipakai adalah 18,5, 19, dan 19,5. Material spesimen uji yang dipakai adalah stanless steel ketebalan $1 \mathrm{~mm}$ dan 2 $\mathrm{mm}$. Ukuran spesimen uji stanless steel $100 \mathrm{~mm} \times 50$ $\mathrm{mm}$ untuk ketebalan $1 \mathrm{~mm}$ dan $2 \mathrm{~mm}$. Adapun hasil pengujian tekuk dapat dilihat dalam Tabel 2.

Berdasarkan proses yang telah dilakukan mulai dari perancangan, pembuatan, perakitan hingga pengujian die set, maka dapat dijelaskan bahwa perancangan die set dapat dilakukan dengan menggunakan software Autodesk Fusion 360 untuk memudahkan dalam proses pembuatan dalam bentuk gambar kerja. Penggunaan software Autodesk Fusion 360 juga telah dilakukan untuk merancang press tool V-air bending [7].

Selanjutnya, pembuatan die set juga telah dilakukan dengan menggunakan mesin perkakas yang dikerjakan sesuai ukuran dan bentuk yang ada dalam gambar kerja yang telah disiapkan. Tahap berikutnya adalah proses perakitan terhadap semua komponen baik yang dibuat maupun yang dibeli untuk memperoleh satu die set yang lengkap.

Tahap akhir adalah proses pengujian tekuk terhadap die set tersebut dengan menempatkan dalam mesin uji tekan (UTM Galdabini). Pengujian tekuk ini dimaksudkan untuk mengetahui kemampuan dan performance tekuk terhadap pelat bahan stainless steel dengan parameter yang telah ditentukan. 
Tabel 2. Hasil pengujian tekuk pada stainless steel ketebalan $1 \mathrm{~mm}$ dan $2 \mathrm{~mm}$

\begin{tabular}{|c|c|c|c|c|c|c|c|}
\hline \multirow[t]{2}{*}{ No } & \multirow{2}{*}{$\begin{array}{l}\text { Radius } \\
\text { Punch } \\
\text { (mm) }\end{array}$} & \multirow{2}{*}{$\begin{array}{l}\text { Sudut } \\
\text { Punch } \\
\text { (mm) }\end{array}$} & \multirow{2}{*}{$\begin{array}{l}\text { Punch } \\
\text { Travel } \\
(\mathrm{mm})\end{array}$} & \multicolumn{2}{|c|}{$\begin{array}{l}\text { Gaya Tekuk } \\
\text { (Newton) }\end{array}$} & \multicolumn{2}{|c|}{$\begin{array}{l}\text { Sudut Tekuk } \\
\text { (derajat) }\end{array}$} \\
\hline & & & & Tebal $1 \mathrm{~mm}$ & Tebal $2 \mathrm{~mm}$ & Tebal $1 \mathrm{~mm}$ & Tebal $2 \mathrm{~mm}$ \\
\hline 1 & 2 & 80 & 19,5 & 125 & 130 & $110^{\circ} 50^{\prime}$ & $104^{\circ} 20^{\prime}$ \\
\hline 2 & 4 & 80 & 19,5 & 105 & 131 & $109^{\circ} 20^{\prime}$ & $103^{\mathrm{O}}$ \\
\hline 3 & 6 & 80 & 19,5 & 95 & 120 & $110^{\circ} 30^{\prime}$ & $102^{\circ} 25^{\prime}$ \\
\hline 4 & 2 & 85 & 19,5 & 106 & 129 & $111^{\circ} 10^{\prime}$ & $102^{\circ} 55^{\prime}$ \\
\hline 5 & 4 & 85 & 19,5 & 116 & 145 & $112^{\circ} 10^{\prime}$ & $101^{\circ} 45^{\prime}$ \\
\hline 6 & 6 & 85 & 19,5 & 107 & 126 & $111^{\circ} 5^{\prime}$ & $100^{\circ} 20^{\prime}$ \\
\hline 7 & 2 & 90 & 19,5 & 106 & 137 & $111^{\circ} 25^{\prime}$ & $102^{\circ}$ \\
\hline 8 & 4 & 90 & 19,5 & 102 & 126 & $111^{\circ} 35^{\prime}$ & $103^{\circ} 20^{\prime}$ \\
\hline 9 & 6 & 90 & 19,5 & 105 & 163 & $111^{\circ} 20^{\prime}$ & $99^{\circ} 10^{\prime}$ \\
\hline 10 & 2 & 80 & 19,0 & 115 & 131 & $109^{\circ}$ & $104^{0} 15$ \\
\hline 11 & 4 & 80 & 19,0 & 106 & 124 & $109^{\circ} 10^{\prime}$ & $103^{\circ} 10^{\prime}$ \\
\hline 12 & 6 & 80 & 19,0 & 94 & 113 & $111^{\circ} 20^{\prime}$ & $104^{\circ} 15^{\prime}$ \\
\hline 13 & 2 & 85 & 19,0 & 103 & 129 & $112^{\circ} 40^{\prime}$ & $103^{\circ} 15^{\prime}$ \\
\hline 14 & 4 & 85 & 19,0 & 114 & 140 & $113^{0} 15^{\prime}$ & $101^{\circ} 15^{\prime}$ \\
\hline 15 & 6 & 85 & 19,0 & 107 & 124 & $112^{\circ} 35^{\prime}$ & $100^{\circ} 40^{\prime}$ \\
\hline 16 & 2 & 90 & 19,0 & 104 & 129 & $108^{\circ} 20^{\prime}$ & $104^{\circ} 15^{\prime}$ \\
\hline 17 & 4 & 90 & 19,0 & 102 & 120 & $112^{\circ} 25^{\prime}$ & $116^{\circ} 45^{\prime}$ \\
\hline 18 & 6 & 90 & 19,0 & 104 & 135 & $113^{\circ} 5^{\prime}$ & $102^{\circ} 30^{\prime}$ \\
\hline 19 & 2 & 80 & 18,5 & 111 & 130 & $107^{\circ} 45^{\prime}$ & $106^{\circ} 35^{\prime}$ \\
\hline 20 & 4 & 80 & 18,5 & 103 & 122 & $113^{\circ}$ & $105^{\circ} 5^{\prime}$ \\
\hline 21 & 6 & 80 & 18,5 & 92 & 113 & $113^{\circ}$ & $104^{\circ} 20^{\prime}$ \\
\hline 22 & 2 & 85 & 18,5 & 102 & 124 & $112^{\circ} 50^{\prime}$ & $104^{\circ} 10^{\prime}$ \\
\hline 23 & 4 & 85 & 18,5 & 114 & 130 & $113^{\circ} 30^{\prime}$ & $103^{\circ} 50^{\prime}$ \\
\hline 24 & 6 & 85 & 18,5 & 105 & 121 & $115^{\circ} 20^{\prime}$ & $104^{\circ} 35^{\prime}$ \\
\hline 25 & 2 & 90 & 18,5 & 104 & 125 & $115^{\circ} 45^{\prime}$ & $105^{\circ} 40^{\prime}$ \\
\hline 26 & 4 & 90 & 18,5 & 101 & 115 & $115^{\circ} 15^{\prime}$ & $105^{\circ} 10^{\prime}$ \\
\hline 27 & 6 & 90 & 18,5 & 102 & 122 & $114^{\circ} 30^{\prime}$ & $105^{\circ} 15^{\prime}$ \\
\hline
\end{tabular}

Adapun hasil pengujian tekuknya menunjukkan bahwa gaya tekuk yang diperlukan dalam penekukan pelat stainless steel dengan ketebalan $1 \mathrm{~mm}$ adalah berkisar $92 \mathrm{~N}-125 \mathrm{~N}$, sedangkan untuk ketebalan 2 $\mathrm{mm}$ berkisar $113 \mathrm{~N}-163 \mathrm{~N}$. Adapun sudut tekuk (bending) yang dihasilkan adalah $107^{\circ} 45^{\prime}-115^{\circ} 45^{\prime}$ untuk ketebalan $1 \mathrm{~mm}$, dan $100^{\circ} 20^{\prime}-116^{\circ} 45^{\prime}$ untuk ketebalan $2 \mathrm{~mm}$.

\section{Simpulan}

Berdasarkan hasil perancangan dan pembuatan die set sebagai press tool untuk penekukan pelat bahan stainless steel, maka dapat disimpulkan beberapa hal, antara lain:

- Die set berserta komponennya didesain dengan menggunakan software Auodesk Fusion 360 (educational licence 2019)

- Pembuatan die set dilakukan dengan menggunakan mesin perkakas sesuai dengan gambar kerja hasil desain, dan selanjutnya dirakit menjadi satu die set yang lengkap.

- Hasil pengujian tekuk menunjukkan bahwa die set telah menunjukkan performansi dan memenuhi syarat sebagai press tool yang dapat menekuk pelat bahan stainless steel.

\section{Ucapan Terima Kasih}

Pemberian ucapan terima kasih atau penghargaan yang sebesar-besarnya kepada Kementerian Pendidikan dan Kebudayaan yang telah mendanai penelitian (Kontrak Penelitian Tahun Jamak Penelitian Terapan Nomor: B/49/PL10.13/PT.01.05/2021). Tak lupa juga diucapkan terima kasih kepada Direktur PNUP dan Ketua P2M PNUP yang memberikan kesempatan untuk mengikuti program Penelitian Terapan Unggulan Perguruan Tinggi ini serta semua pihak yang terlibat dalam penelitian ini.

\section{Daftar Pustaka}

[1] M. A. Suyuti, M. Iswar, R. Nur, and E. Erniyanti, "Desain Konstruksi Press Tool Sebagai Alat Bending Bentuk V Dengan Garis Bending Max. 300mm," J. Sinergi Jur. Tek. Mesin, 2019.

[2] Ö. Tekaslan, N. Gerger, and U. Şeker, "Determination of spring-back of stainless steel sheet metal in 'V' bending dies," Mater. Des., vol. 29, no. 5, pp. 1043-1050, 2008.

[3] M. A. Suyuti, "Rancang Bangun Simpel Press Tool untuk Bending V Bottoming," J. Tek. Mesin SINERGI, vol. 13, no. 2, pp. 160-173, 2019.

[4] R. Nur and M. A. Suyuti, "Mini Press Tool as Learning Practical: Designing, Manufacturing, and Analysis," J. Ind. Eng. Manag. Res., vol. 1, no. 2, pp. 9-14, 2020.

[5] Autodesk, "Fusion 360." 2019.

[6] G. Verma, Autodesk fusion 360 black book. BPB Publications, 2018.

[7] M. A. Suyuti, R. Nur, and M. Iswar, "Rancang Bangun Press Tool Untuk Alat Bending Pelat Tipe Die-V Air Bending," Mach. J. Tek. Mesin, vol. 6 , no. 1, pp. 39-45, 2020. 


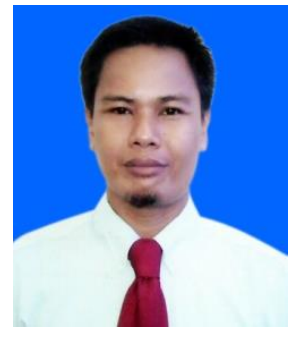

Rusdi Nur menyelesaikan pendidikan D3 Teknik Mesin Politeknik dan S1 Teknik Mesin Universitas Hasanuddin pada tahun 1995 dan 1999. Oleh karena ada program pemerintah pengangkatan Dosen Politeknik, maka mengambil program D4 Teknik Manufaktur Politeknik Manufaktur Bandung selama dua tahun (1999-2001). Pendidikan S2 Teknik Mesin Universitas Hasanuddin (2006-2008).

Pada tahun 2016 ia menyelesaikan pendidikan doktoral (Ph.D) bidang Teknik manufaktur di Universiti Teknologi Malaysia, Johor Malaysia. Saat ini ia bekerja sebagai dosen di Jurusan Teknik Mesin Politeknik Negeri Ujung Pandang. Bidang penelitian utama yang digeluti adalah sustainable manufacturing, forming process, welding process, and machining process. Beliau telah menerbitkan beberapa buku yang berISBN, antara lain: Pengantar Sistem Manufaktur, Perancangan MesinMesin Industri, dan Teknologi Manufaktur.

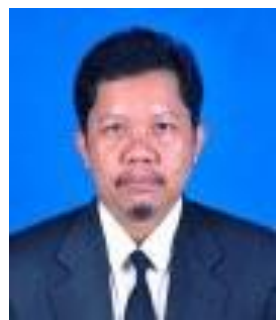

Muhammad Arsyad Suyuti menjalani pendidikan D3 Teknik Mesin Politeknik Universitas Hasanuddin (1992-1995) dan S1 di Universitas Hasanuddin (1996-1999). Pada tahun 1999-2001, beliau memperoleh program beasiswa calon dosen PNUP pada program studi D4 Teknologi Rekayasa Manufaktur di Politeknik Manufaktur Bandung (POLMAN Bandung).

Pada tahun 2008 menyelesaikan pendidikan magister di Universitas Hasanuddin, Makassar dibidang teknik industri. Beliau mengambil program Doktoral di Universitas Brawijaya Malang. Saat ini ia bekerja sebagai dosen program studi D4 Teknik Manufaktur di Jurusan Teknik Mesin Politeknik Negeri Ujung Pandang (PNUP) Makassar. Bidang penelitian utama yang digeluti adalah materials \& design, manufacturing technology dan Design \& Modeling Engineering.

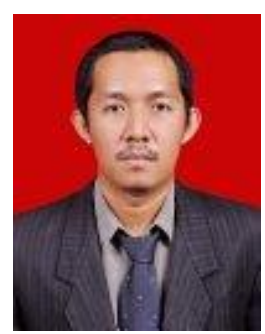

Muhammad Iswar menjalani pendidikan D3 Teknik Mesin Politeknik Politeknik Negeri Ujung Pandang (1998-2001) dan melanjutkan studi pada D4 Teknik Rekayasa Manufaktur di Politeknik Manufaktur Bandung (2001-2002). Setelah melalui seleksi CPNS, Beliau menjadi dosen tetap Jurusan Teknik Mesin Politeknik Negeri Ujung Pandang (PNUP) Makassar sejak tahun 2005.

Pada tahun 2010 menyelesaikan pendidikan magister di Universitas Hasanuddin, Makassar dibidang Teknik Mesin. Bidang penelitian utama yang digeluti adalah permesinan, pengelasan, manufacturing technology dan Design \& Modeling Engineering. 